\title{
A review of employee engagement: Empirical studies
}

\author{
Halid Hasan $^{\text {a }}$, Farika Nikmaha ${ }^{\text {a }}$, Siti Nurbaya ${ }^{a}$, Nilawati Fiernaningsih ${ }^{a}$, Ellyn Eka Wahyu ${ }^{a}$
}

${ }^{a}$ Business Administration Department, State Polytechnic of Malang, Indonesia

\begin{tabular}{l}
\hline C H R O N I C L E \\
\hline Article history: \\
Received: December 20, 2020 \\
Received in revised format: \\
January 202021 \\
Accepted: March 22, 2021 \\
Available online: \\
March 22, 2021 \\
\hline Keywords: \\
Employee engagement \\
Human resources management \\
Organizational competitive ad- \\
vantage
\end{tabular}

1. Introduction

In the 2000s most companies started to focus on both management systems and human resources since not only IT, but human resources also play an important role in the company to keep on surviving and adapting toward changes. The fact that human, as a resource, is crucial to work alongside other resources had by the company is proved by some researches done by Ployhart et al (2014) mentioned that employees are the most important asset; humans came to be regarded as an asset instead of a resource, ones that could be developed continuously, renewed, and protected (Bayraktar \& Sencan, 2017); Whether it is people, workforce, intellectual capital, human capital, human resources, talent, or any other term, the resource contained in employees and their organization is increasingly recognized as critical to strategist and competitive advantage (Gabcanova, 2011). Human resource is asset for the company competitive advantage, so if the company wants to hold them tight, it is necessary to give the employees a push, stimulation and assurance that they are the integral part of the company. Managing people is a piece of art. Companies in the 21st century must be able to adopt technology and be innovative in managing employees, emphasis on artistic processes in strategic management and daily activities (Adler, 2006). People management is not easy. This is not an exact science. In fact, it is seen as an art that is mastered by people with experience. Managing human resource issues, people are the most important assets, how companies can maintain and employees have a positive perception of their workplace (Stockley, 2006).

The art mentioned above means that handling employees cannot be done in the same way from time to time, today the condition is totally different from what happened 10years ago. The generation changes, we have what we called the millennial generation who will work as employees. Many companies nowadays do some development in their working atmosphere to * Corresponding author.

E-mail address: farikanikmah@gmail.com (F. Nikmah)

(C) 2021 by the authors; licensee Growing Science, Canada doi: $10.5267 / \mathrm{j} . \mathrm{msl} .2021 .3 .013$ 
match with millennial characteristics, for example Gojek is averagely dominated by27-year-old employees. It applies the flexibility and office-hour free working culture. This company also gives the broader room for their employees to solve the problem in their own way with their own responsibility. Maintaining employees is becoming more difficult in a borderless world. Employees can engage only when the company creates a good corporate brand, ensuring that employees have a good job that makes it feel proud to work for the company. Employees have the opportunity to improve their experience, competence and quality. Psychological compensation must be given by the company, if not, the employee will resign (Narkhede \& Joshi, 2014; Dongre \& Narkhede, 2015). A company should understand well the needs of each employee since their needs are different from each other. It is necessary to understand the motivations and needs of employees and how these concepts relate to individual goals and behavior. Although all people have the same urges, they do not have the same emotional reactions (such as loneliness, curiosity, or anger) or needs in the same situation (McShane \& Glinow, 2010). See Fig. 1.

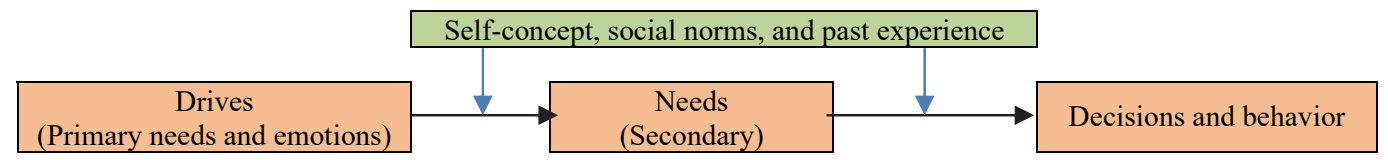

Fig.1. Drives, Needs, and Behavior

Source: Mc Shane, et al., (2010)

The above figure explained that each employee is affected by self-concept, social norm and past experience in behaving and making decisions in which they have already been built up based on their primary and secondary need. The same concept works in the choice of employee's engagement. Khan (1990) defines engagement as the harnessing of organization members' selves to their work roles. In engagement, an employee expresses themselves physically, cognitively, and emotionally during role performance. Engagement is a motivational construct. Another definition by Schaufeli et al. (2006) mentioned engagement as a positive, fulfilling, work-related state of mind that is characterized by vigor, dedication, and absorption. Engagement is characterized by energy, involvement, and efficiency. (Maslach \& Leiter, 2016). Engagement as a form of well-being has been defined by many authors (Harter \& Schmidt, 2002; Schaufeli, Bakker, \& Salanova, 2006; Bakker \& Demerouti, 2008; Gorgievski, Bakker, \& Schaufeli, 2010; Rich, Lepine, \& Crawford, 2010; Rothbard \& Patil, 2011; Albrecht, 2012; Bakker \& Oerlemans, 2011; Mayo \& Jackson, 2018).

This research was conducted by analyzing the results of the previous studies to make sure that the study about engagement experienced some kind of development. It develops from year-to-year along with the development of the employee's need, complexity of the human basic need, employee's generation, and disruption era that also change the environment and business atmosphere which are somehow unpredictable. Previously, engagement was the physical involvement, cognitive and emotion of the employee to their company (Kahn, 1990), but the following studies show that engagement is more than that. Some research that was conducted after 1990 can be used as the reference, so it is interesting to be studied deeply by using Khan's study as the basis for the further studies. In the following there are some studies that were used as a reference by Kahn (1990) as the base of the studies which are the development of engagement research topics.

\section{Literature Review}

Researches used as references by Kahn (1990)

Researches which are mentioned that engagement/disengagement is affected by the employee's need on self-expression and self-employment, (Maslow, 1954; Eden, 1973; Hackman \& Oldham, 1976); job involvement behavior (Mitchell \& Baba, 1975; Blau \& Boal, 1987; Blau \& Boal, 1989), alienation (Blauner, 1964; Seeman, 1975), flow (Cziksentmihalyi \& Harper, 1990); personal voice (Hirschman, 1984), intrinsic motivation (Reeve \& Deci, 1986), meaningfulness (Thapisa, 1989); (Langer \& Moldoveanu, 2006); ethical behavior (Panzl \& McMahon, 1989), creativity (Perkins, 1985), emotional (Rafaeli \& Sutton, 1987) and commitment (Gibb, 1961; Mowday, Porter, \& Steers, 2013; Porter, Steers, \& Boulian, 1973).

Researches done by Khan initiated by an opinion that each person can use his/her physical, cognitive and emotional ability to take part in achieving the maximum working performance that would be implicated in the working result and experience. By having those things mention previously, it can be concluded that engaged employee is determined by three physical conditions: meaningfulness, safety and availability. Some study tried a different concept with the previous studies which stated that a special condition of being engaged and disengaged was shown by the role of the employee related to the performance. The special condition here is the people's emotional reaction to conscious and unconscious phenomena and the objective properties of jobs, roles and work contexts; the primacy of people's experiences of themselves and their contexts as the mediator of people's experience of themselves and their contexts as the mediator of the depths to which they employ and express or withdraw and defend themselves during role performance; and the self in role as the unit of analysis, a focus on how both person and role are enlivened or deadened during role performance. This study generated a conceptual model by developing more components than the previous ones. Khan seriously considered the chosen components and their effect on the personal, interpersonal, group, and intergroup and organization that creating a choice to be fully engaged or disengaged. Based on those components, the personal chooses to be fully engaged or modestly engaged toward their working role in a certain company. This study analyzed a person's choice to be engaged or disengaged by understanding the motives behind the choice. It is like 
using a camera by zooming the lenses to make the far object looks closer, so the unseen thing will be clearly shown, in this case is the reason of being engaged or disengaged.

Researches conducted after 1990

The researches in this period of time stated that engagement/disengagement is determined by the employee's need on selfexpression and self-employment (Abbas \& Murad, 2012; Reeve \& Lee, 2014), job involvement behavior (Engelbrecht \& Heine, 2016; Bakker \& Demerouti, 2008; Gorgievski, Bakker, \& Schaufeli, 2010; Schaufeli, Bakker, \& Salanova, 2006; Schaufeli, Shimazu, Hakanen, \& Salanova, 2017; Shuck, Rocco, \& Albornoz, 2010), intrinsic motivation (Sartono \& Ardhani, 2015; Masvaure, Ruggunan, \& Maharaj, 2014), meaningfulness (May, Gilson, \& Harter, 2004); creativity (Gichohi, 2014; Davis, 2007; Yoo \& Jeong, 2017), emotional (Pilotti et al., 2017; Yoo \& Jeong, 2017), commitment (Dajani, 2015; Albrecht, 2012; Nazir \& Islam, 2017; Farndale et al., 2014), well-being (Guest, 2014; Bakker \& Oerlemans, 2011; Scott-Jackson \& Mayo, 2018; Shuck \& Reio Jr, 2014; Joo \& Lee, 2017; Hakanen \& Peeters, 2018) work motivation and work satisfaction (Harter \& Schmidt, 2002; Albrecht, 2012; Sartono \& Ardhani, 2015; Masvaure et al., 2014; Farndale et al., 2014), performance (Guest, 2014; Rich et al., 2010; Yongxing et al., 2017; Sendawula et al., 2018; Kim et al., 2012; Dajani, 2015), work life balance (Pandita \& Singhal, 2017; Shekhar, 2016; Jaharuddin \& Zainol, 2019; Larasati \& Hasanati, 2018), corporate entrepreneurship (Afework \& Raju, 2015; Bakytgul et al., 2019; Ghura \& Goel, 2018; Dhanpat \& Schachtebeck, 2019; Umair, Asif et al., 2018), psychological contract (Kasekende, 2016; Heshmati \& Jed, 2015; Sharma \& Garg, 2017; Naidoo et al., 2019), discretionary behaviors (Kasekende, 2016; Piyachat et al., 2014); innovation (Jonas et al., 2018; Fatima \& Khan, 2017); service climate (Fung et al., 2017; Menguc, 2017; Chaudhary et al., 2014; Salanova et al., 2005), service quality (Fung et al., 2017; Dharmaputra \& Aruan, 2017; Barkhuizen et al., 2014; Hapsari et al., 2016), organizational citizenship behavior (Farndale et al., 2014; Mathumbu \& Dodd, 2013; Kataria et al., 2013; Shantz et al., 2015).

\section{Methods}

This study was done by applying the literature review based on the studies done by Kahn (1990). The researchers assumed that the study by Kahn (1990) is the starter of the development of studies focus on engagement topic. By using the qualitative method, this study described narratively as a hope to help in explaining the model and gives suggestion for the further researchers. The result shown in the conclusion is a result of reviewing some studies to be used as empirical reference (King \& $\mathrm{He}, 2005)$. Generally, narrative explanation is criticized for being biased, so here, the study was done by following the systematic guideline of managements (Levy \& Ellis, 2006; Tranfield, Denyer, \& Smart, 2003; Webster \& Watson, 2002). The guideline mentions the analysis steps that started by searching and identifying, next is aggregation- combining and grouping the identifying result-, and the last step is analyzing- determining the closest match of the theory and empirical review.

\section{Processing}

1. Input

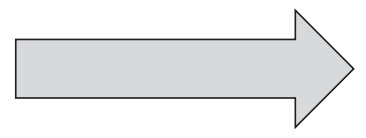

1. Know the literature

2. Comprehend the literature

3. Apply

4. Analyze

5. Synthesize

6. Evaluate

Fig. 2. Analysis steps

Source: Levy et al. (2006)

\section{Results}

Based on the analysis steps, the review started by doing identification toward some studies done by previous researchers. The engagement topic could be seen as having developed after the period of Khan's study that was in 1990. Khan used the psychological approach by giving attention to a scientific study of body endurance to reach its optimal function (Seligman \& Csikszentmihalyi, 2000). This approach was done as an effort to add the focus of the traditional psychology, only focus on disease, organ damage, mental disorder and disability. This traditional psychological review was added with organizational psychology, by measuring the strength and ability of human resources to be positively developed and managed to increase working performance (Youssef \& Luthans, 2007). The engagement study is getting evolved in which engagement is defined as the involved feeling of an employee toward his/her organization. Engaging here means being involved in terms of body, mind, and high sense of belonging toward the organization that makes the personal sometimes forgets the body endurance and leads to tiredness. Is an employee who experiences tiredness categorized as engaged? This is the debatable question that drives some studies to give more explanation on this presumption. Tiredness here is called burnout which is defined as a psychological syndrome of emotional exhaustion, depersonalization and reduced personal accomplishment that can occur among professionals who work with other people in some capacity". (Maslach, 1993). On the progress, there is a paradigm that occurred called The Maslach Burnout Inventory (MBI). The occurrence of this paradigm causes some arguments discussing the relation between burnout and engagement. The argument popped up after two study results which mentioned that the 
purpose of the study was to measure the engagement. MBI mentioned that emotional exhaustion, depersonalization, and personal accomplishment (and in future it changed into exhaustion, cynicism, and professional inefficacy) as the measurement scale that stated by giving highest score of the negative answer if it was related to engagement (Maslach \& Jackson, 1981). Next, it was also claimed that giving the highest score of the answer was categorized as showing high efficacy and accomplishment at work, but without the existence of exhaustion or cynicism (Maslach \& Leiter, 2008). Then, the engagement measure was developed by using The Utrecht Work Engagement Scale (UWES) which explain that engagement as a persistent, positive affective-motivational state of fulfillment with three dimensions of measurement: vigor, dedication, and absorption (Schaufeli et al., 2006; Salanova et al., 2005; Schaufeli et al., 2017; Schaufeli et al., 2001). During the progress, engagement measurement by using MBI and UWES had no longer argued, whether MBI and UWES are opposite or stand by themselves, so if the research is purposed to measure engagement, it has directly mentioned to be applied by using MBI or UWES. Many researchers chose to use UWES as the measurement tool since it has a positive opinion toward engagement. If a person intentionally chose to be engaged, it is sure that he/she will do the work happily with high involvement and loyalty although he/she feels tired, it is seen as something usual during working time. Based on some studies conducted in Khan's period, mostly used UWES with some kinds of development. It happened in line with the more complex phenomenon related to human resources: people change, human need and the development of technology. In the following are some developments in the result of the study about engagement using UWES as the measuring tool and some development items used as the additional parameter. It is considered as the second step, grouping the study results that have been done previously based on the additional parameter that given according to the purpose of the study that aimed to achieve.

\begin{tabular}{|c|c|}
\hline Additional Parameter & Result \\
\hline $\begin{array}{l}\text { Motivation; psychological } \\
\text { need }\end{array}$ & $\begin{array}{l}\text { Human beings have different needs, so as the willing of being engaged and disengaged are affected by motivation, mean- } \\
\text { ingfulness, safety and availability in specific situations. If they are not well managed, the person who chooses to be en- } \\
\text { gaged will experience stress, alienation, dependency and deterministic utility for him/ herself. }\end{array}$ \\
\hline $\begin{array}{l}\text { Job and personal resource; } \\
\text { workaholism; workplace } \\
\text { environmental }\end{array}$ & $\begin{array}{l}\text { By adding some parameters in UWES (vigor, dedication, absorption) measurement, the workaholic employee is different } \\
\text { from the engaged employee. Workaholic is assumed as a bad attitude (working excessively and working compulsively) } \\
\text { while engagement is a positive attitude, it is more to passion for work. External influence gives a chance for an employee } \\
\text { to engage, both in job resource and personal resource. Next is the workplace environment, in which for them working is } \\
\text { a daily life like being together with the second family. }\end{array}$ \\
\hline Intrinsic motivation & $\begin{array}{l}\text { Intrinsic motivation is more on the self-push, having interest, and doing for likeness not for money and status. Intrinsic } \\
\text { motivation is not the trigger of employee engagement. The relationship is weak especially if there is no other stimulus. } \\
\text { Some studies tried self-efficacy as the moderation. Although intrinsic motivation cannot be expected by the organization, } \\
\text { an organization has to treat its employee respectfully and on the other hand, the employee has the moral responsibility } \\
\text { toward the organization by giving loyalty and respect. }\end{array}$ \\
\hline $\begin{array}{l}\text { Creativity; innovation; or- } \\
\text { ganizational culture; learn- } \\
\text { ing process }\end{array}$ & $\begin{array}{l}\text { Creativity mentioned as the personal ability to create something new that is beneficial in the long term for the organization } \\
\text { as the competitive advantage. Creativity is identical with innovation. Creativity should be stimulated by the organization } \\
\text { and generally related to organizational culture. Employees need to be involved from the beginning until the organizational } \\
\text { outcome. It is done to give meaningful learning to build their knowledge and skills. The involvement is called creativity } \\
\text { engagement where the employee has a chance to join in solving the problem, do an experiment, and create a new idea. } \\
\text { Besides, interaction with more people will make the employees get used to accepting critique, suggestion, and marking } \\
\text { during the process of developing creativity. }\end{array}$ \\
\hline Emotional & $\begin{array}{l}\text { Emotional is the individual reaction that shows the mood at the very moment, whether he/she is happy, sad, or annoyed. } \\
\text { Emotional is the expression of feeling. Some studies mentioned above chose to use UWES measurement by adding some } \\
\text { parameters, while in this study, the researcher used the psychological approach by Khan: psychological meaningfulness, } \\
\text { psychological availability and psychological safety. The employee reaction is the form of positive emotion in which it can } \\
\text { be formed, fixed and helps strengthen the relationship between the organization and the employees. Employees are not } \\
\text { money machines but meaningful assets for the organization to respect and be appreciated based on their working perfor- } \\
\text { mance. }\end{array}$ \\
\hline $\begin{array}{l}\text { Commitment; organiza- } \\
\text { tional justice; organizational } \\
\text { support; leadership, perfor- } \\
\text { mance }\end{array}$ & $\begin{array}{l}\text { Engagement as the moderating to arrive at the employee's commitment to reach the performance. Employee engagement } \\
\text { occurs when there is some stimulus to strengthen it such as fairness, organizational support, and a leader that gives room } \\
\text { for the employee to do their duty and accept their right based on what they deserve. There are some other incentives that } \\
\text { make the employees engaged with the organization such as compensation, employee improvement etc. Stated in some of } \\
\text { the studies, when employees are engaged, they are more likely to be committed, Commitment is considered as the crucial } \\
\text { organizational issue because commitment is the degree to which an employee is willing to exert energy and feel pride for } \\
\text { being with the organization. }\end{array}$ \\
\hline $\begin{array}{l}\text { Well-being; job satisfac- } \\
\text { tion; workplace environ- } \\
\text { ment; psychological capital; } \\
\text { experience positive emo- } \\
\text { tions. }\end{array}$ & $\begin{array}{l}\text { Well-being as well as higher performance, commonly mentioned as employee happiness. Using a psychological approach, } \\
\text { well-being occurs when the employees are satisfied with their work, by maximizing the psychological capital owned by } \\
\text { the employee (self-efficacy, hope, resiliency, and optimism), so during doing the working they will get experience of } \\
\text { positive emotion such as happiness, joy and enthusiasm. Employees in this condition are able to show high productivity } \\
\text { because happiness is more sensitive to opportunities at work, more outgoing and helpful to others, and more confident } \\
\text { and optimistic, and then they will transfer their engagement to others. Most time will be spent to work, there is a balance } \\
\text { between working and leisure. Good working environment and support from organizations give chance to get employees } \\
\text { who are engaged, do the work happily and a high sense of belonging to find new family in their working environment. } \\
\text { Based on the study, it can improve individual and organizational performance and to enhance employees' well-being. }\end{array}$ \\
\hline $\begin{array}{l}\text { Work motivation; work sat- } \\
\text { isfaction, productivity; initi- } \\
\text { ative; }\end{array}$ & $\begin{array}{l}\text { Initiative is the extent to which employees accept personal responsibility to be proactive to improve aspects of their work. } \\
\text { Engagement in some research related to employee innovative and proactively seeking opportunities. Based on some stud- } \\
\text { ies that related to work motivation and satisfaction, not with the engagement. The productive employee has higher moti- } \\
\text { vation in working and satisfied with the working but not engaged with the organization. The reason why the employee } \\
\text { has no engagement is not clear but the prediction is: financial factor, business growth direction, future organization con- } \\
\text { dition which make the employee always be ready in finding the best opportunity, resign and move to another organization } \\
\text { that gives the longer future assurance. It affects the increase of employee turnover toward the organization. }\end{array}$ \\
\hline
\end{tabular}


Additional Parameter Performance; organizational commitment; Perceived Organization Support

Work life balance (WLB) Organizational productivity; stress; leisure

\section{Corporate entrepreneurship}

Psychological contract
Many studies that measure the effect of employee engagement toward the performance. It is stated that some indicators to achieve engagement level such as: material and immaterial, training, culture, support, organization commitment and other. Ideally, employee performance should be firstly created to reach the organization performance, but the fact is good organizational performance is not always the parameter of good employee performance. The unevenness of the competence and skill had by each employee caused by the unclear training program and probably only for a certain level of employee. The organization support and commitment do not reach the lower level employee, they are only for the ones that are on top.

WBL as the amount of time spent on doing a job compared to the amount of time spent with family and doing things they may enjoy. The need of an employee 20 years ago is totally different from the nowadays employee. Most employees nowadays are the millennial generation who like flexible working hours, but still with high productivity. For the millennial, working with the help of technology means that they do not have to be in the office to finish their work. They are still very productive and have optimal contribution for the organization, it is important for them to live in balance, not spend most of their time in the office. They need the time to be with their family, travelling and use their little time for their hobby. It is proved that this generation experiences less stress since they spend their leisure time to recharge their energy, have positive thoughts, and relax. Are they not productive? The answer to this question is surprising, they are very productive, do their job happily which makes them finish their work on time so they do not need to bring their work home. It makes them have much time to do the family activity. So, productivity is not measured by the presence in the office because the nowadays generation work with the technology help that is not limited by the place and time.

Entrepreneurship can be defined as a process encompassing activities such as the creation of wealth, the creation of enterprise, the creation of innovation, the creation of change, the creation of employment, the creation of value and the creation of growth. The research provides that corporate entrepreneurship enables employees of an organization to utilize their passion and energy towards crafting new ways of developing competitive advantage for business growth or alternately provide practically different ways of doing existing business. Corporate entrepreneurship is perceived important, because it not only assists organizations to obtain a better competitive position but also contributes to the economy of a country at large by boosting productivity at national level. This is because the productivity level and growth at national level are a function of the collection of industries and industry segments in which a nation's firms can

Successfully compete in the global market.

It is mentioned as an individual belief about right and duty as an employee toward themselves and organization owner. Psychological contract is made based on the same contract law: the law about the duty or the promise made based on the duty and hope of both parties. Some studies mentioned that employees feel there is no improvement from the first year up to the recent time. The company insists them to do more than their duties that are supposed to be the right of the employee. Almost all of the studies stated that the company failed in fulfilling their duty/ promise that has been mentioned in the beginning. The employee usually feels disappointed that will decrease their performance and lead to resignation.

It is actually a behavior of the employee that is not acknowledged by the organization explicitly. Discretionary behaviors, some studies call it altruism, courtesy, sportsmanship, conscientiousness and civic virtue, also can increase loyalty. Innovation processes are seen to be highly complex, uncertain, multi-faceted, and dynamic activities. Innovative work behavior requires some level of internal, sustaining force that pushes individuals to persevere in the face of challenges inherent to creative work. Individuals with personal strengths are greatly engaged in their job and have the ability to regulate their work environment effectively, for sure play some role related to innovative behavior. Employees who have many creative ideas will not be afraid in sharing knowledge. For him/ her sharing knowledge will not reduce the knowledge, on the other hand, when he/she gets feedback, he/she will complete the idea to make it useful in the developing process. Knowledge sharing as a transfer or flow of knowledge. It is the process of exchanging, receiving and benefiting from others experiences and knowledge. It is a collaborative effort with a mutual exchange of knowledge, which results in a joint effort of creating new knowledge.

Service climate as the employee perceives the practices, procedures, and behaviors that get rewarded, supported, and expected with regard to customer service and customer service quality or as simply service climate as the degree to which management emphasizes service quality in all of its activities. Other research said the incremental role of climate strength over climate quality in explaining individual and organizational outcomes based on the attraction, selection, attrition model and organizational socialization literature. The results found imply that creating a climate of human resource development is a compelling intervention, which could provide competitive advantage to the firm in terms of enhanced work engagement levels among employees.

Employees can only deliver a quality service if the organization supports them through resources, training, management practices, and assistance. Employees who are happy, satisfied, engaged to the company are important capitals because employees are companies' representation when delivering services to customers. Companies engaged in services can invest and pay more attention to facilities and infrastructure, while not forgetting to its employees and creating a solid working team.

Organizational citizenship behavior refers to the willingness of employees to go beyond the formal specifications of work roles, also known as extra-role behaviors. Explained these forms of behavior as informal, with people who engage in them going beyond what is formally expected of them to contribute to the well-being of their organization. OCB are discretionary behaviors that contribute to the organization by fostering a social environment that is conducive to the accomplishment of work, and includes such behaviors as helping others, advocating the organization, and attending functions not formally required by the organization. The enactment of proactive activities implies going beyond core task behavior by developing new strategies or pursuing alternative goals in relation to the organization.

Next step is analyzing as the third step or the last step done in reviewing. Based on the reviewing that has been done previously, the topic of engagement is still popular and interesting to be conducted as a review (Farndale et al., 2014; Bakker \& Demerouti, 2008; Guest, 2014; McShane \& Glinow, 2010). It is because employee engagement is seen as the cornerstone of high performing organizations. Studies showed that employee engagement give long term positive effect and also being the excellence for the organizational competitive advantage (Heshmati \& Jed, 2015). Positive perception and motivation of the employees about the organization where they work can be effective stimuli for engagement (Albrecht, 2012; Farndale et al., 2014; Harter \& Schmidt, 2002; Masvaure et al., 2014; Sartono \& Ardhani, 2015). Next, some support of the organization such as leadership, workplace environment, organizational justice, organizational support, organizational culture, learning process, experience can be the hope for the employee and value on the organizational management. The employee will consider to work longer in 
the organization and reduce the turnover (Blau \& Boal, 1987; Blau \& Boal, 1989; Jaharuddin \& Zainol, 2019; Mowday et al., 2013; Youssef \& Luthans, 2007).

Organizations often mistakenly assume that employees have the same universal needs, beliefs and values. In fact, the involvement of employees depends on what is being needed at the time. Employees do it based on motives of need. Individual differences, circumstances and personal needs vary greatly (Maslow, 1954; McShane \& Glinow, 2010). Organization should imply the open management system, the employees have the right to engage in all organization process, aside from building the relationship with the employee, identify the specific values from each employee, what their important thing is, directly or indirectly will make the employee feel that the organization pay attention to them, give them reward, support them as individual. The result of involving employees is the organization will find a strength had by each employee. The same level employee does not always have the same skill and competence, there will always be a difference such as habit and hobby that can be used to enhance the personal performance and the following result enhances the organization performance. For example, there is an employee who is a risk taker, while the others are not. The same case happens with creativity, initiative and innovation. They will not be the same to each other. The task for the organization is to guide all the excess had by the employees based on the necessity. If the employee is a risk taker, the organization can assign him/her to explore and evaluate the new technology that can be used to improve the internal organization stability such as social networking tools. Organization needs to spend some time having a discussion with the employees and with a little sacrifice will give a huge impact. It will lead to the pop up of innovation from the employee that will ease the organization do some innovation (Davis, 2007; Gichohi, 2014; Jonas et al., 2018; Fatima \& Khan, 2017; Yoo \& Jeong, 2017).

Modern organizations are full of employees from the millennial generation. The lifestyle and working style is different with the previous generations. The millennial is an open characteristic, spontaneous in telling opinions, both agree and disagree, and have less interest in spending most of the time working. They prefer to have a balanced life. They do not like a typical work that takes most of their time, while they want to enjoy certain time to do activities apart of working such as gathering with their family, doing hobbies, and other leisure activities. It becomes a challenge for the organization that they have to change their paradigm, working culture although the fact that the organization should follow the changes is unavoidable. For the millennial employees that have already adapted well with technology, IT makes their life easier and faster in finishing their work. Working does not always have to have a presence in the office, for them working can be everywhere and anywhere since IT makes the world have no limit. This fact results that this millennial is physically stronger, has less stress, works happily but still have high productivity (Jaharuddin \& Zainol, 2019; Larasati \& Hasanati, 2018; Shekhar, 2016; Pandita \& Singhal, 2017). The highest engagement is when the employee is satisfied with the organization, show high commitment as part of the organization, show some behaviors that support the organization such as loyalty, discretion behavior, no interest in changing job, have citizenship behavior such as behave in both formal and informal way, proud being the part of the organization where they work for (Kasekende, 2016; Piyachat et al., 2014; Farndale et al., 2014; Mathumbu \& Dodd, 2013; Kataria et al., 2013; Shantz et al., 2015).

\section{Discussion, Implications and Limitations}

In many organizations, employees are viewed as an asset to be managed rather than as individuals who can create the next innovation for success. Long-term engagement starts with good communication between employer and employees as well as among co-workers, fostering a positive working environment. Engagement researchers have shown increasing interest to achieve the company performance (Guest, 2014; Rich et al., 2010; Yongxing et al., 2017; Kim et al., 2012; Dajani, 2015; Sendawula et al., 2018). A different level of analysis about a certain concept about hierarchical relationship occurs in all organizational phenomena which have a presence in nested arrangement. The study about engagement grows fast such as the topic that discuss about the relationship between employee engagement and organizational performance (Guest, 2014; Rich et al., 2010; Yongxing et al., 2017; Kim et al., 2012; Dajani, 2015; Sendawula et al., 2018), employee engagement as the stimuli of the arisen of employee commitment toward the company (Dajani, 2015; Albrecht, 2012; Farndale et al., 2014; Nazir $\&$ Islam, 2017). Other topics that are suitable with the recent issues and need to make the growth of the theory about human resource and organization.

The fact that human beings are a resource that cannot be treated in the same way because of the different basic need. Human resource management cannot be done in a strict way, it needs flexibility and easiness to be able to adapt toward the changes in society and business needs, so managing employees is an art (Adler, 2006). Employee in an organization is like a crowd that works together in an orchestra. There is the one who leads and is led. The leader played the role as the key who swung the stick to create a rhyme. It can be slow, fast, stomping or rhythmic as the result of the work of the ones who are led. Each person in the crowd is not only expert in playing one instrument, but they also are able to work together creating harmony. The similar situation happens in an organization, it consists of a lot of people with their own ability in their own field that support the organization. Though, there is something that should be remembered by the organization is that each person contribute differently like an orchestra, though some people are not in the stage such as the ones in charge in providing consumption for the 
Those are employees, they are assets (Stockley, 2006). Having employees that are engaged with the organization bring advantages to the organization, giving excellence to the company (Bayraktar \& Şencan, 2017). Although there is a phenomenon that the place for human resources can be replaced by IT sophistication, human resources are still needed for certain types of job that cannot only depend on the database consisting of some orders without analysis.

The limit of this study is not completely accommodated with the research results that are used as the empirical study, there is a possibility that some results are not attached which probably are important to the development of the engagement topic. The limit as the researcher of the data source and searching method. Hopefully in the next study which has the same topic, the data can be fully accommodated to make a comprehensive analysis that can represent the review study and be used to answer some problem related to engagement.

\section{References}

Abbas, R. Z., \& Murad, H. (2012). Extending “Kahn's model of personal engagement and disengagement at work" with reference to existential attributes: A case study of HR managers in Pakistan. International Journal of Social Economics, $4(1), 2-31$.

Adler, N. J. (2006). The Arts \& Leadership: Now That We Can Do Anything, What Will We Do? Academy of Management Learning \& Education, 5(4), 486-499.

Afework, K. G., \& Raju, R. (2015). Investigating the relationship between corporate entrepreneurship and employee engagement. Journal of Entrepreneurship in Emerging Economies, 7(2), 148-167.

Albrecht, S. L. (2012). The influence of job, team and organizational level resources on employee well-being, engagement, commitment and extra-role performance Test of a model. International Journal of Manpower, 33(7), 840-853.

Bakker, A. B., \& Demerouti, E. (2008). Towards a model of work engagement. Career Development International, 13(3), 209-223.

Bakytgul, T., Ahmed, M., \& Kim, Y. (2019). Corporate Entrepreneurship and Organizational Performance: The Moderating Role of Organizational Engagement. International Association of Educators and Researchers, 1(1), 89-102.

Barkhuizen, N., Mogwere, P., \& Schutte, N. (2014). Talent Management, Work Engagement and Service Quality Orientation of Support Staff in a Higher Education Institution. Mediterranean Journal of Social Sciences, 5(4), 112-134.

Bayraktar, O., \& Şencan, H. (2017). Employees' Approaches to Human Resources from the Asset-Resource Concepts Perspective. International Journal of Business and Social Science, 3(1), 55-72.

Blau, G. J., \& Boal, K. B. (1987). Conceptualizing How Job Involvement and Organizational Commitment Affect Turnover and Absenteeism. Academy of Management Review, 12(2), 78-92.

Blau, G., \& Boal, K. (1989). Using Job Involvement And Organizational Commitment Interactively to Predict Turnover. Journal of management, 15(1), 19-30.

Chaudhary, R., Rangnekar, S., \& Barua, M. K. (2014). Organizational climate, climate strength and work engagement. Procedia - Social and Behavioral Sciences, 2(2), 434-446.

Dajani, M. A. (2015). The Impact of Employee Engagement on Job Performance and Organisational Commitment in the Egyptian Banking Sector. Journal of Business and Management Sciences, 3(5), 138-147.

Davis, S. (2007). Drama, Engagement and Creativity. Central Queensland: Global Conference, 1(2), 250-273.

Dhanpat, N., \& Schachtebeck, C. (2019). Corporate Entrepreneurship: It's a Matter of Engagement. International Business Conference, 2(1), 178-289.

Dharmaputra, J., \& Aruan, D. (2017). Analysis of Team Engagement and Physical Servicescape Perception Effects on Branch Service Quality and Customer Engagement. Atlantis Press, 1(2), 300-320.

Eden, D. (1973). Self-Employed Workers: A Comparison Group For Organizational Psychology. Organizational Behavior and Human Performance, 9(1), 78-100.

Engelbrecht, A. S., \& Heine, G. (2016). Integrity, ethical leadership, trust and work engagement. Leadership \& Organization Development Journal, 38(3), 368-379.

Farndale, E., Beijer, S. E., Veldhoven, M. J., Kelliher, C., \& Hailey, V. H. (2014). Work and organisation engagement: aligning research and practice. Journal of Organizational Effectiveness: People and Performance, 1(2), 157-176.

Fatima, A., \& Khan, M. A. (2017). Do Hope Foster Innovative Work Behavior through Employee Engagement and Knowledge Sharing Behavior? A Conservation of Resources Approach Using MPLUS tool. Business \& Economic Review, 9(4), 181-212.

Fung, C., Sharma, P., Wu, Z., \& Su, Y. (2017). Exploring service climate and employee performance in multicultural service settings. Journal of Services Marketing, 7(1), 784-798.

Gabcanova, I. (2011). The employees-the most important asset in the organizations. Human Resources Management \& Ergonomics, 3(1), 154-167.

Gichohi, P. M. (2014). The Role of Employee Engagement in Revitalizing Creativity and Innovation at the Workplace: A Survey of Selected Libraries in Meru County Kenya. Library Philosophy and Practice, 1(2), 1171-1184.

Gorgievski, M. J., Bakker, A., \& Schaufeli, W. (2010). Work engagement and workaholism: comparing the self-employed and salaried employees. The Journal of Positive Psychology, 2(1), 83-96. 
Guest, D. (2014). Employee engagement: a sceptical analysis. Journal of Organizational Effectiveness: People and Performance, 1(2), 141-156.

Hackman, ]. R., \& Oldham, G. R. (1976). Motivation through the Design of Work: Test of a Theory. Organizational Behavior and Human Performance, 16(2), 40-55.

Hakanen, J. J., \& Peeters, M. (2018). Different Types of Employee Well-Being Across Time and Their Relationships With Job Crafting. Journal of Occupational Health Psychology, American Psychological Association, 23(2), 289-301.

Hapsari, R., Clemes, M. D., \& Dean, D. (2016). The impact of service quality, customer engagement and selected marketing constructs on airline passenger loyalty. International Journal of Quality and Service Sciences, 9(1), 21-40.

Harter, J. K., \& Schmidt, F. L. (2002). Business-Unit-Level Relationship Between Employee Satisfaction, Employee Engagement, and Business Outcomes: A Meta-Analysis. Journal of Applied Psychology, 87(2), 268-279.

Heshmati, B., \& Jed, S. (2015). Relationship of psychological contract and employees' job engagement (An investigation of the millennium generation and the impacts of various generations). International Letters of Social and Humanistic Sciences, 62(1), 16-26.

Jaharuddin, N. S., \& Zainol, L. N. (2019). The Impact of Work-Life Balance on Job Engagement and Turnover Intention. The South East Asian Journal of Management, 13(1), 89-101.

Jonas, J. M., Sörhammar, D., \& Moeslein, K. (2018). Stakeholder engagement in intra- and inter-organizational innovation: Exploring antecedents of engagement in service ecosystems. Journal of Service Management, 29(3), 399-421.

Joo, B.-K., \& Lee, I. (2017). Workplace happiness: work engagement, career satisfaction, and subjective well-being. Evidence-based HRM: a Global Forum for Empirical Scholarship Emerald Publishing Limited, 5(2), $206-221$.

Kahn, W. A. (1990). Psycological Conditions of Personal Engagement and Disengagement at Work . Academy of Management Journal, 33(4), 692-724.

Kasekende, F. (2016). Psychological contract, engagement and employee discretionary behaviours: Perspectives from Uganda. International Journal of Productivity and Performance Management, 66(7), 896-913.

Kataria, A., Garg, P., \& Rastogi, R. (2013). Employee Engagement and Organizational Effectiveness: The Role of Organizational Citizenship Behavior. JBIT, 6(1 ), 138-148.

Kim, W., Kolb, J., \& Kim, T. (2012). The Relationship Between Work Engagement and Performance: A Review of Empirical Literature and a Proposed Research Agenda. Human Resource Development Review, 12(3), 248-276.

King, W. R., \& He, J. (2005). Understanding the role and methods of meta analysis in is research. Communications of the Association for Information Systems, 16(1), 665-686.

Langer, E. J., \& Moldoveanu, M. (2006). The Construct of Mindfulness. Journal of Social Issues, 2(2), 23-35.

Larasati, D. P., \& Hasanati, N. (2018). The Effects of Work-Life Balance towards Employee Engagement in Millennial Generation. 4th ASEAN Conference on Psychology, Counselling, and Humanities, Levy, Y., \& Ellis, T. J. (2006). A Systems Approach to Conduct an Effective Literature Review in Support of Information Systems Research. Informing Science Journal, 9(1), 200-212.

Maslach, C., Schaufeli, W., \& Leiter, M. (2001). JOB BURNOUT. Annu. Rev. Psychol, 2(1), 397-422.

Maslach, C., \& Leiter, M. ( 2016 ). Understanding the burnout experience: recent research and its implications for psychiatry. World Psychiatry, 6(1), 1-15.

Maslach, C., \& Jackson, S. E. (1981). The measurement of experienced burnout. John Wiley \& Sons, Limited, 2(1), 99-113.

Maslach, C., \& Leiter, M. (2008). Early Predictors of Job Burnout and Engagement. Journal of Applied Psychology, 93(3), 498-512.

Masvaure, P., Ruggunan, S., \& Maharaj, A. (2014). Work Engagement, Intrinsic Motivation and Job Satisfaction among Employees of a Diamond Mining Company in Zimbabwe. Journal of Economics and Behavioral Studies, 6(6), 488-499.

Mathumbu, D., \& Dodd, N. (2013). Perceived Organisational Support, Work Engagement and Organisational Citizenship Behaviour of Nurses at Victoria Hospital. Journal of Psychology, 4(2), 87-93.

May, D. R., Gilson, R., \& Harter, L. (2004). The psychological conditions of meaningfulness, safety and availability and the engagement of the human spirit at work. Journal of Occupational and Organizational Psychology, 77(2), 11-37.

Mayo, A., \& Jackson, W. S. (2018). What are Engagement, Happiness and Well-Being? Journal of Work and Organizational Psychology 3(1), 67-80.

Menguc, B., S, A., \& V, Y. (2017). The role of climate: Implications for service employee engagement and customer service performance. Journal of the Academic Marketing Sciences, 45(3), 40-49.

Mitchell, V. F., \& Baba, V. (1975). On the Relationship Between Job Involvement and Central Life Interest. Journal Industrial Relations, 30(2), 123-139.

Naidoo, V., Abarantyne, I., \& Rugimbana, R. (2019). The impact of psychological contracts on employee engagement at a university of technology. Journal of Human Resource Management, 2(1), 80-102.

Narkhede, P. A., \& Joshi, S. P. (2014). Challenges of Human Resource Management in Borderless world. Global Journal of Management Science, 2(1), 13-30.

Nazir, O., \& Islam, J. (2017). Enhancing organizational commitment and employee performance through employee engagement: An empirical check. South Asian Journal of Business Studies, 6(1), 98-114 .

Pandita, S., \& Singhal, R. (2017). The Influence of Employee Engagement on the Work-Life Balance of Employees in the IT Sector. Journal of Organizational Behaviour, 16(1), 62-78.

Perkins, D. N. (1985). Postprimary education has little impact on informal reasoning. Journal of Educational Psychology, 2(1), 562-571. 
Pilotti, M., Anderson, S., Hardy, P., Murphy, P., \& Vincent, P. (2017). Factors Related to Cognitive, Emotional, and Behavioral Engagement in the Online Asynchronous Classroom. International Journal of Teaching and Learning in Higher Education, 29(1), 145-153.

Piyachat, B., Chanongkorn, K., \& Panisa, M. (2014). The Mediate Effect of Employee Engagement on the Relationship between Perceived Employer Branding and Discretionary Effort. Business \& Economics Review, 24(1), 59-72.

Ployhart, R. E., \& Fulmer , I. (2014). “Our Most Important Asset”: A Multidisciplinary/ Multilevel Review of Human Capital Valuation for Research and Practice. Journal of Management, 40(1), $161-192$.

Reeve, J., \& Deci, E. (1986). Element of the Competitive Situation That Affect Intrinsic Motivation. Personality and Social Psychology, 22(1), 82-98.

Reeve, J., \& Lee, W. (2014). Students' Classroom Engagement Produces Longitudinal Changes in Classroom Motivation. Journal of Educational Psychology, 1(2), 222-242.

Rich, B. L., Lepine, J. A., \& Crawford, E. R. (2010). Job Engagement: Antecedents and Effect on Job Performance. Academy of Management, 53(3), 617-635.

Salanova, M., Agut, S., \& Peiro, J. (2005). Linking Organizational Resources and Work Engagement to Employee Performance and Customer Loyalty: The Mediation of Service Climate. Journal of Applied Psychology, 90(6), 74-90.

Salanova, M., Sonia, A., \& Peiro, J. M. (2005). Linking Organizational Resources and Work Engagement to Employee Performance and Customer Loyalty: The Mediation of Service Climate. Journal of Applied Psychology, 90(6), 12171227.

Sartono, H., \& Ardhani, M. (2015). Work Engagement, Intrinsic Motivation and Job Satisfaction among Employees of A Coal Mining Company in South Borneo. International Research Journal of Business Studies, 7(2), 108-115.

Schaufeli, W. B., Bakker, A. B., \& Salanova, M. (2006). The Measurement of Work Engagement With a Short Questionnaire A Cross-National Study. Educational and Psychological Measurement Sage Publications 2(2), 701-716.

Schaufeli, W. B., Salanova, M., Roma, V. G., \& Bakker, A. B. (2001). The measurement of engagement and burnout: A two sample confirmatory factor analytic approach. Journal of Happiness Studies, 3(1), 71-92.

Seligman, M. E., \& Csikszentmihalyi, M. (2000). Positive Psychology: An Introduction. American Psychologist, 55 (1), 5-14.

Sendawula, K., Kimuli, S., Bananuka, J., \& Muganga, G. (2018). Training, employee engagement and employee performance: Evidence from Uganda's health sector. Int Journal of Social Sciences Management and Entrepreneurship, 5(1), $147-160$.

Shantz, A., Alfes, K., Truss, C., \& Soane, E. (2015). The role of employee engagement in the relationship between job design and task performance, citizenship and deviant behaviours. The International Journal of Human Resource Management $12(1), 112-230$.

Sharma, N., \& Garg, P. (2017). Psychological Contract and Psychological Empowerment as Employee Engagement Drivers in Indian IT Sector. International Journal of Applied Business and Economic Research, 15(1), 86-99.

Shekhar, T. (2016). Work life Balance \& Employee Engagement- Concepts revisited. International Journal of Pure and Applied Sciences, 5(1), 36-46.

Shuck, B., \& Reio Jr, T. (2014). Employee Engagement and Well-Being: A Moderation Model and Implications for Practice. Journal of Leadership \& Organizational Studies, 21(1), 43-58.

Shuck, M. B., Rocco, T., \& Albornoz, C. (2010). Exploring employee engagement from the employee perspective: implications for HRD. Journal of European Industrial Training, 35(4), 300-325.

Tranfield, D., Denyer, D., \& Smart, P. (2003). Towards a Methodology for Developing Evidence-Informed Management Knowledge by Means of Systematic Review. British Journal of Management, 14(2), 207-222.

Umair, A., Asif, Q. M., Hussain, S. M., \& Muhammad, K. F. (2018). Nurturing innovation performance through corporate entrepreneurship: the moderation of employee engagement. Studies in Business and Economic, 13(2), 14-22.

Webster, J., \& Watson, R. T. (2002). Analyzing the past to prepare for the future: writing a literature revieW. MIS Quarterly, 26(2), 13-21.

Yongxing, G., Hongfei, D., Baoguo, X., \& Lei, M. (2017). Work engagement and job performance: the moderating role of perceived organizational support. Annals of Psychology, 33(3), 708-713.

Yoo, J., \& Jeong, J. (2017). The effects of emotional labor on work engagement and boundary spanner creativity. Asia Pacific Journal of Innovation and Entrepreneurship, 11(2), 214-232.

Youssef, C. M., \& Luthans, F. (2007). Positive Organizational Behavior in the Workplace: The Impact of Positive Organizational Behavior in the Workplace: The Impact of Hope, Optimism, and Resilience. Journal of Management, 1(1), $774-800$. 
(C) 2021 by the authors; licensee Growing Science, Canada. This is an open access article distributed under the terms and conditions of the Creative Commons Attribution (CC-BY) license (http://creativecommons.org/licenses/by/4.0/). 